that our work is very often scientific research work of the highest character, and that although we are very often told that because of its practical nature it does not belong to pure science, yet we should insist that, whether it be pure science or not, it is scientific work, and because of our previous training is likely to be of permanent value.

I desire, finally, to offer an apology for the shortcomings probably altogether too visible in this address, and to express the hope that Section D of the American Association for the Advancement of Science, because of the large and important field which it represents, will start in on a new era of prosperity.

UNIVERSITY OF WISCONSIN.

\section{STORM Bull.}

FAUNA AND FLORA OF PUERTO RICO.

IN the past the island of Puerto Rico was densely populated. Before Columbus discovered America and Ponce made his first European settlement on the island there had been two races on it, and each had occupied practically the whole of it. The first was, to judge by its shell heaps and other remains, a people of Northern origin, and the other was of the Carib race. At the time of the occupation by the Spanish the population was, according to their reports, as dense as it is now. It is now the most densely populated rural community proper on the continent of America. It has upwards of 230 inhabitants to the square mile, and this is strictly rural, as it has no great cities, the largest being of less than 40,000 inhabitants. The people generally live in the country, and the country huts are scattered in all sorts of places, expected and unexpected, from the crests of the mountains to the coasts.

Under these conditions only a very small original or wild fauna can be expected. Generally speaking, the largest wild mam- mal is a ground squirrel, about the size of a gopher. A few others of larger size are reported from time to time, but they are only occasional and are probably animals escaped from cultivation. Probably the larger animals once existed, and their traces could doubtless be found by a linguist in the place names which abound all over the island and are quite often not Spanish, but these creatures have been so long gone that they are not even mentioned by the natives, nor do the customary traditions otherwise refer to them.

The largest bird on land is the pretty white heron, of about the same size as the common heron of the Northern States. It belongs in the swamps. The nightingale is not rare, and sometimes in winter some of the Northern songbirds are seen, but in general the avian fauna is very sparse. The song and twitter of the birds is very rarely heard. Along the coasts the pelican, large and clumsy looking, except on the water, is very common where it is very much occupied with its profession of fisherman. It prefers protected harbors to the open water outside, and shows no greater shyness of man than to keep in the less disturbed waters of the ports.

The most common quadruped, by all odds, is the little lizard or swift, which can be seen almost anywhere in the sun and even frequently penetrates houses and lives with the family. They are very quick, intelligent, cleanly creatures and are only dangerous to cockroaches, flies and other small vermin. The largest land reptile is a snake, which sometimes reaches six or eight feet in length, something like the black snake, but called a python. It does no harm, so far as learned. There are a few other species of less size whose venom is not yet proved and is not feared by the natives.

The land crabs, snails and other such creatures are far from common, except in marshy places and near the coast. The 
largest crab seen in some months' residence was a brilliantly colored pink and black one which belonged exclusively in the mangran swamps. Its very bright, clean coloring, its commonness there and its movements, characterized by a certain shifty handiness, make it a very striking object.

The greatest attraction of Puerto Rico for its tropical position is its relative freedom from insects, especially the noxious and troublesome ones. The scorpion and centipede are so rare that they are very seldom spoken of by the natives, and the so-called tarantula is only an overgrown spider, so far as learned not so large as that of New Mexico. The cockroach is common enough and sometimes reaches an enormous size before his fate overtakes him. Mosquitoes are generally not troublesome. Doubtless there are spots and seasons for an abundance of them, but these are not easy to find. The easterly breeze so com mon over the island and usually felt from afternoon to morning keeps these insects down.

The malignant germs of disease are not so much at home in Puerto Rico as in most other parts of the shores of the Caribbean. They can be introduced there and under favorable circumstances may have a considerable run-much as they would on the Gulf Coast of the States. The island is known as the healthiest of the Antilles and its winter season especially is most wholesome and charming.

The wild plant life has suffered equally with the wild fauna by the prolonged and all-pervading cultivation the island has received. Each part of the island not absolutely uncultivatable, even steep declivities, has been cultivated again and again, and even now slopes are carefully prepared for crops which are steeper than anything probably thus used in the States. They are so inclined that a loosened stone will roll down hundreds of feet and the cultivator hoes at nearly the level of his head.
The wild plants have little chance except on lands which for various reasons may have been neglected. In such places jungle and woods rapidly cover up the traces of cultivation and a few years change a field into a forest. There are many places that look like forests that are in a high state of cultivation, for many of the crops of Puerto Rico require shade when young and windbreaks when older. These crops may be grown in a natural forest from which all unnecessary trees and brush have been removed, or, more often, the man who owns the place makes a planted forest out of trees of certain species suited to protect the plants. Thus it happens that the isiand is much more generally forest-covered than its highly cultivated condition would indicate. Coffee is the crop most cultivated in this way.

The palms are few in kinds and in individuals. The commonest are the cocoa and the cabbage palm. The former loves the salt air from the ocean, but on this insular area it can be found at the greatest distance from the sea, here not more than twenty miles or so. The palm trees furnish thatch, standards, joists and siding for the native huts of the country, and the cabbage at the apex of the cabbage palm is used for food, though each cabbage costs a palm tree.

There are besides some scores of useful timber trees in the island, but they do not often occur in trunks large enough for the saw mill. The total number of such trees on the island must be considerable, but they are scattered, not in continuous forests, and are about as likely to be in villages as in the country. Besides, the wood is often too hard and the trunk too irregular and unsymmetrical for convenient use in the mill. The virgin forests are very few, perhaps none strictly virgin. There are in the mountains some areas that have the appearance of virgin forests, but they do 
not have many large trees, and possibly do not date from many scores of years back. The Island of Culebra, a small island lying to the east of Puerto Rico and belonging to it, is said to be covered by virgin forests. There are several species of tree ferns on the island, always occurring at some distance back from the coast-and on the northern slope, so far as observed. They rarely surpass twenty feet in height.

Meadows have to be made, and for this a crab grass and a festuca or fescue-grass are used. The former is a good strong grass for the meadow and also makes an abundant, excellent, high-green hay. The hay could be imported into New York at a less cost than the inferior hay. from up in the State, and could be brought into the market still fresh in the winter and early spring. The fescue is a better grazing grass and grows with great rapidity and to great height when it can support itself on shrubby vegetation. Cattle graze in it up to the brisket, and in protected places along the fences it is often seen from ten to fifteen feet high.

Mark W. Harrington.

THE BOTANICAL SOCIETY OF AMERICA.

THE sessions of the 5 th annual meeting of the Society were held on Friday and Saturday, August 18th and 19th, in Townshend Hall. The meeting was called to order by the retiring President, Dr. N. L. Britton, who then resigned the chair to the President.elect, Professor L. M. Underwood.

Officers elected for the ensuing year were :

President: Professor B. L. Robinson, Harvard University.

Vice-President : Professor B. D. Halsted, Rutgers College.

Secretary: Professor G. F. Atkinson, Cornell University.

Treasurer: Dr. Arthur Hollick, Columbia University.

Councillors : Professor D. P. Penhallow, McGill
University, and B. T. Galloway, U. S. Dept. of Agriculture.

New members elected were:

Professor J. M. Macoun, Canadian Geological Survey.

Dr. W. J. Beal, Agricultural College of Michigan. Dr. C. F. Millspaugh, Field Columbian Museum.

Dr. M. A. Howe, Columbia University.

On Friday evening the retiring President, Dr. N. L. Britton, delivered a public illustrated address in the chapel of University Hall, on : ' Report of Progress of the Development of the New York Botanical Garden.'

The following papers were read at the several sessions of the Society, in addition to which a number of others were read by title :

'Apetaly and Dioeciousness.' Professor C. E. Bessey, University of Nebraska.

'Symbiosis and Saprophytism' Dr. D. T. MacDougal, New York Botanical Garden.

'The Effect of Centrifugal Force upon the Cell.' Professor D. M. Mottier, University of Indiana.

'The American Species of Arisæma.' Dr. N. L. Britton, New York Botanical Garden.

'The Classification of Botanical Publications.' Professor Wm. Trelease, Missouri Botanical Garden. Arthur Hollick, Secretary pro tem.

\section{SCIENTIFIC BOOKS.}

Naturalism and Agnosticism. The Gifford Lectures delivered before the University of Aber. deen in the years 1896-1898. By JAMES WARD. Two volumes: The Macmillan Co. 1899.

The purpose of Ward's two volumes is not to defend scientific naturalism from the implication of agnosticism, but to show that the only way to escape from the 'determinism ' of the naturalist is through philosophical idealism. The book is able and thoughtful and original, and one which all students of science would do well to study. For this reason I shall make no attempt to present a summary of its contents, although I shall try to call the attention of those who have read the book to a point of view which is very different from that of the author. 